\title{
PETERNAKAN SAPI VERTIKAL BERKELANJUTAN
}

\author{
Merry Suryani ${ }^{1)}$ dan Suwardana Winata ${ }^{2)}$
}

${ }^{1}$ Mahasiswa Program Studi S1 Arsitektur, Fakultas Teknik, Universitas Tarumanagara, merrysuryani9@gmail.com

2 Dosen Program Studi S1 Arsitektur, Fakultas Teknik, Universitas Tarumanagara, suwardanaw@dtt.untar.ac.id

\begin{abstract}
Abstrak
Pemanasan global sekarang menjadi isu dunia yang mengancam masa depan bumi. Beberapa upaya dilakukan untuk mengurangi kerusakan alam seperti pemanasan global. Namun banyak yang tidak sadar bahwa pemanasan global disebabkan oleh kegiatan sehari hari yang kita lakukan dan bahkan pemanasan global juga disebabkan oleh makanan yang kita makan sehari-hari terutama daging sapi. Sebanyak $26 \%$ dari total gas rumah kaca dihasilkan oleh sektor agrikultur dan setengahnya berasal dari ternak sapi. Gas rumah kaca yang dihasilkan oleh sapi ini berupa gas tubuh yaitu gas metana yang lebih berpotensi lebih buruk 21 kali lipat dibandingkan dengan karbondioksida. Bahkan gas rumah kaca yang dihasilkan sapi sama banyaknya dengan segala kendaraan di muka bumi dijadikan satu. Tetapi dibalik dampak besar yang dihasilkan oleh sapi, kebutuhan akan protein menjadi hal yang krusial dalam keberlangsungan hidup manusia dan bahkan menjadi budaya. Sehingga sumber protein hewani ini tidak dapat kita musnahkan begitu saja karna akan berdampak sangat besar dari segi kesehatan hingga ekonomi. Dari isu tersebut maka diajukan proyek yang dikiranya dapat membantu untuk menyelesaikan isu global warming tanpa harus menghilangkan sumber protein tersebut dengan cara menangkap gas tubuh yang dihasilkan sapi, mengolah kotoran yang dihasilkan sapi dan memprosesnya menjadi barang yang berguna serta sistem bangunan yang berkelanjutan dan mandiri.
\end{abstract}

Kata kunci: budaya; pemanasan global; industri; protein; keberlanjutan

\begin{abstract}
Global warming is a world issue that threatens the future of the earth. several attempts were made to reduce damage to nature such as global warming. However, many people are not aware that global warming is caused by our daily activities and even global warming is also caused by the food we eat everyday such as beef. As much as $26 \%$ of total greenhouse gases is produced by the agricultural sector and half comes from cattle. The greenhouse gas produced by cows is in the form of body gas, methane, which is 21 times worse than carbon dioxide. Even the greenhouse gases produced by cows are as much as all the vehicles on earth put together. Behind the huge impact produced by cows, the need for protein is crucial for human survival and even becomes a culture. So that this source of animal protein cannot be eliminated just like that because it will have a huge impact from a health to an economic point of view. From this issue, I propose a project which he thinks can help solve the global warming issue without having to eliminate the protein source by capturing body gas produced by cows, processing cow dung and processing it into useful goods and building systems that are sustainable and independent.
\end{abstract}

Keywords: culture; global warming; industry; protein; sustainable

\section{PENDAHULUAN}

\section{Latar Belakang}

Global warming saat ini menjadi salah satu masalah global yang belum terselesaikan. Global warming sendiri disebabkan oleh banyak hal dan salah satu penyebab terbesarnya adalah sektor agrikultur yang telah menyumbang $26 \%$ dari total karbon di dunia terutama peternakan sapi yang mana angka tersebut lebih besar dibandingkan bidang transportasi. Global warming 
dari sektor agrikultur ini sebenarnya dikarenakan gas metana yang diproduksi oleh tubuh sapi. Selain itu global warming juga diperparah dengan adanya pembakaran hutan karena kurangnya lahan untuk peternakan yang kemudian menjadi masalah serius selanjutnya dari ekosistem protein ini.

Indonesia sendiri berperan besar sebagai salah satu negara yang permintaan akan daging sapi yang terus meningkat. Menurut Asian-Australasian Journal of Animal Science, permintaan daging sapi dengan persediaan daging sapi di Indonesia akan terus meningkat hingga tahun 2024 tanpa penurunan sama sekali, namun menurut data yang dilampirkan, persediaan daging sapi di Indonesia masih lebih sedikit dibanding permintaan, sehingga impor daging sapi tidak dapat dihindari. Hal ini juga akan menjadi ancaman bagi lingkungan jika tidak adanya penanganan terkait isu global warming yang disebabkan hewan ternak.

\section{Rumusan Permasalahan}

Berdasarkan isu efisiensi protein yang cukup serius, maka muncul permasalahan mengenai peningkatan efisiensi dalam proses beternak sapi melalui arsitektur serta memanfaatkan secara maksimal sisa atau buangan yang dihasilkan oleh sapi maupun pendukung pengembangan ternak seperti makanan, proses pemotongan maupun pengelolaan ternak melalui perencanaan dan perancangan arsitektur.

\section{Tujuan}

Tujuan dari proyek ini adalah untuk menciptakan wadah arsitektural yang mendukung proses dan pengelolaan ternak secara efisien serta untuk untuk dapat menciptakan sistem pendukung efisiensi pengelolaan ternak, khususnya sapi.

\section{KAJIAN LITERATUR}

\section{Melampaui Ekologi}

Secara singkat, ekologi adalah ilmu yang mempelajari organisme dalam tempat hidupnya atau dengan kata lain mempelajari hubungan timbal-balik antara organisme dengan lingkungannya. Ekologi hanya bersifat eksploratif dengan tidak melakukan percobaan, jadi hanya mempelajari apa yang ada dan apa yang terjadi di alam. Pada saat ini dengan berbagai keperluan dan kepentingan, ekologi berkembang sebagai ilmu yang tidak hanya mempelajari apa yang ada dan apa yang terjadi di alam. Ekologi berkembang menjadi ilmu yang mempelajari struktur dan fungsi ekosistem (alam), sehingga dapat menganalisis dan memberi jawaban terhadap berbagai kejadian alam. Struktur ekosistem menurut Odum (1983), terdiri dari beberapa indikator yang menunjukkan keadaan dari sistem ekologi pada waktu dan tempat tertentu. Fungsi ekosistem menggambarkan hubungan sebab akibat yang terjadi dalam sistem. Berdasarkan struktur dan fungsi ekosistem, maka seseorang yang belajar ekologi harus didukung oleh pengetahuan yang komprehensif berbagai ilmu pengetahuan yang relevan dengan kehidupan seperti: taksonomi, morfologi, fisiologi, matematika, kimia, fisika, agama dan lain-lain. Ekologi tidak hanya mempelajari ekosistem tetapi juga otomatis mempelajari organisme pada tingkatan organisasi yang lebih kecil seperti individu, populasi dan komunitas.

Salah satu masalah pada ekosistem dunia merupakan pemanasan global. Pemanasan global adalah kondisi peningkatan suhu rata-rata permukaan bumi akibat konsentrasi gas rumah kaca yang berlebih. Demikian pengertian pemanasan global menurut Natural Resources Defence Council. Dampak pemanasan global juga menurunkan kualitas hidup manusia.

Penyebab pemanasan global terdiri dari berbagai sumber seperti bahan bakar fosil. Manusia mulai mencemari udara secara tidak terkendali dengan menggunakan bahan bakar fosil, batu bara, minyak, gas untuk menjalankan mobil, truk, pabrik-pabrik. Meskipun demikian, bukan 
berarti efek rumah kaca selalu berdampak negatif bagi bumi. Secara umum, efek rumah kaca merupakan hal baik dan dibutuhkan bagi makhluk hidup di bumi. Tanpa gas rumah kaca, suhu di Bumi menjadi terlalu dingin sehingga tidak mungkin ditempati. Namun, jika berlebih, gas rumah kaca akan menyebabkan bumi menjadi terlalu panas. Melampaui ambang batas daya tahan hidup manusia dan berbagai spesies.

Selain itu gas metana menjadi penyebab kedua, terutama oleh peternakan. Peternakan sapi menghasilkan lebih banyak metana dibandingkan industri minyak. Sekitar 20 persen emisi gas metana AS diproduksi oleh gas tubuh yang dihasilkan oleh ternak sapi.

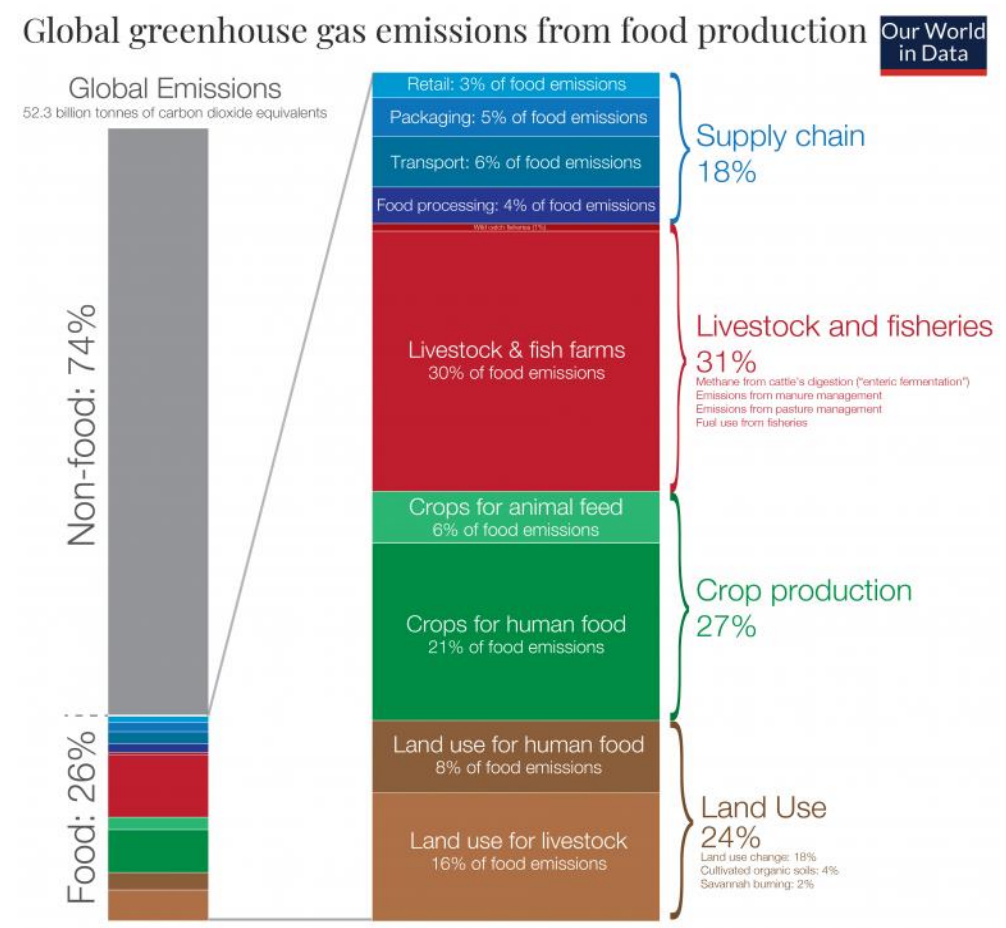

Gambar 1. Persentase Gas Rumah Kaca yang Dihasilkan Makanan Sumber: Poore, J., \& Nemecek, T., 2018

Saat ini, terdapat lebih banyak karbon dioksida di atmosfer dibandingkan dalam kurun waktu 800.000 tahun terakhir. Perubahan iklim global menimbulkan dampak yang dapat diamati pada lingkungan. Gletser mencair, es di sungai serta danau lebih cepat mencair dibandingkan periode sebelumnya. Penyebaran tanaman dan hewan berubah dibandingkan data historis.

\section{Mekanisme terbentuknya gas metana}

Gas metana merupakan tipikal GRK yang diemisi pada sektor pertanian termasuk peternakan, terutama dari ternak ruminansia, yakni sebagai hasil kerja bakteri metanogenik dalam rumen. Gas metana mempunyai pengaruh yang lebih besar dibandingkan dengan gas $\mathrm{CO} 2$ terhadap pemanasan global, karena daya menangkap panas gas metana adalah $25 \times$ CO2 (VLAMING, 2008) Hal ini dapat dijelaskan dengan berbagai mekanisme, antara lain berdasarkan interaksi IR dengan suatu molekul (PETERS et al., 1974)

Produksi gas metana dari seekor sapi dapat mencapai 49,80 kg/ekor/tahun, dengan dasar perhitungan bahwa energi gas metana yang terbentuk adalah $8 \%$ dari energi yang dikonsumsi ternak. Seekor ternak mengkonsumsi bahan kering pakan sekitar $3 \%$ dari bobot hidup. Untuk seekor sapi dengan bobot $300 \mathrm{~kg}$ akan mengkonsumsi bahan kering pakan sekitar $9 \mathrm{~kg}$ per hari. 
Variasi produksi gas metana dapat terjadi antar jenis, bangsa, tipe maupun individu ternak. Suhu lingkungan juga menyebabkan produksi gas metana yang berbeda, dimana suhu rendah cenderung menyebabkan produksi gas metana yang lebih tinggi. Jenis pakan yang dikonsumsi ternak, terutama kandungan bahan organik dan serat juga mempengaruhi besarnya produksi gas metana. Sehubungan dengan hal tersebut, perlu dievaluasi emisi gas metana dan upaya mitigasi gas metana dari ternak untuk mendapatkan gambaran yang lebih akurat dengan mempelajari faktor serta koefisien produksi gas metana dari berbagai faktor yang mempengaruhinya.

Gas metana sendiri secara langsung diproduksi dari dalam tubuh hewan ternak dan dikeluarkan melalui lubang mulut dan juga lubang anus. Pada kasus yang lebih umum, gas metana juga dihasilkan oleh pembakaran kotoran hewan ternak dalam proses pembuatan pupuk dan biogas

\section{Sifat metana}

Pada suhu ruangan dan tekanan standar, metana adalah gas yang tidak berwarna dan tidak berbau. Sebagai gas, metana hanya mudah terbakar bila konsentrasinya mencapai $5-15 \%$ di udara. Metana yang berbentuk cair tidak akan terbakar kecuali diberi tekanan tinggi (4-5 atmosfer).

Metana digunakan dalam proses industri kimia dan dapat diangkut sebagai cairan yang dibekukan (gas alam cair, atau LNG). Ketika dalam bentuk cairan yang dibekukan, metana akan lebih berat daripada udara karena gas metana yang didinginkan akan mempunyai massa jenis yang lebih besar, . Metana yang berada pada suhu ruangan biasa akan lebih ringan daripada udara. Gas alam, yang sebagian besar adalah metana, biasanya didistribusikan melalui jalur pipa.

\section{METODE}

Metode penelitian yang digunakan adalah dengan pengumpulan data secara kualitatif dan juga kuantitatif. Data yang diambil berupa 2 jenis data yaitu data primer dan sekunder

a. Data primer. Data primer merupakan data yang diperoleh langsung oleh peneliti seperti observasi lingkungan tapak dan dokumentasi.

b. Data sekunder berupa data yang telah ada seperti studi kasus dan jurnal

\section{DISKUSI DAN HASIL}

\section{Program}

Terdapat 2 jenis program utama yaitu program produksi dan program pendukung produksi. Secara horizontal terbagi menjadi 2 zona yaitu zona limited area dan public area. Untuk program produksi semuanya masuk kedalam limited area sedangkan program pendukung produksi tersebar di public area dan di limited area. 


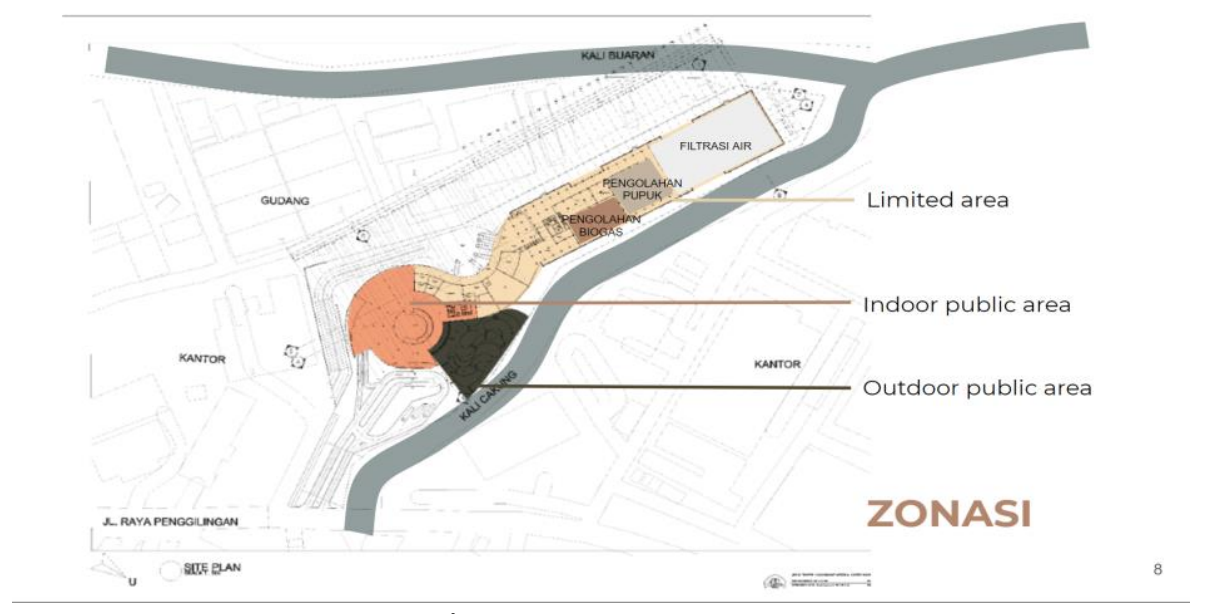

Gambar 2. Zonasi Lantai Satu

Sumber: Penulis, 2021

secara vertikal, proyek ini direncanakan fasilitas pendukung yang bersifat publik di area depan sehingga lebih mudah untuk dijangkau. Pada area tersebut digunakan void besar untuk memberikan kesan lebih terbuka. Untuk area limited berupa area produksi ditempatkan di area belakang untuk membatasi orang masuk dan keluar dan juga lebih efektif secara produksinya karna masing masing fasilitas produksi dekat 1 dengan yang lainnya. Pada area produksi lantai 1, lebih difokuskan terhadap produksi waste yang aktif sedangkan pada lantai 2 difokuskan untuk pergudangan. Pada lantai 3 difokuskan untuk sapi, seperti area karantina, ruang dokter hewan, dan area pemotongan sapi dan pengolahan dagingnya. Pada lantai 4 lebih difokuskan untuk area pemeliharaan sapi dan juga visitor center. Kemudian yang utama dari proyek ini yaitu 3 tower berupa area pemeliharaan.

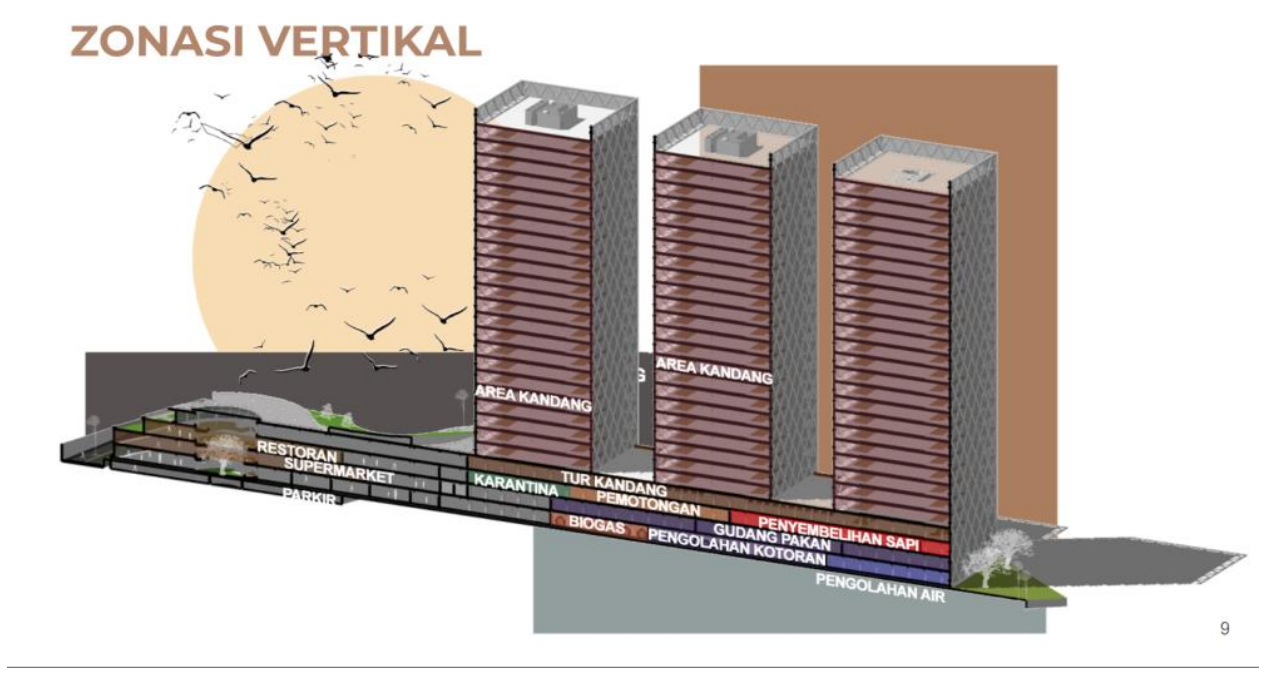

Gambar 3. Potongan Perspektif

Sumber: Penulis, 2021

Area pemeliharaan dibuat berbentuk tower untuk memudahkan sirkulasi untuk semua sistem yang ada disini. Lantai bertingkat memudahkan sirkulasi air, kotoran, pakan dan gas metana untuk bertransportasi. Pada area pemeliharaan ini penggemukkan sapi menggunakan metode jepang dimana sapi dikurangi pergerakannya sehingga pembentukkan lemak menjadi lebih sempurna. Dengan program vertikal, ada beberapa sistem yang dirancang untuk mendukung 
kehidupan sapi berupa tabung angin yang akan menghembuskan angin ke setiap kandang, sehingga sapi tetap merasa nyaman. Terdapat pipa pakan ternak untuk menyalurkan pakan berupa fodder crops dan pakan konsentrat secara otomatis. Untuk pakan berupa fodder crops, seeds akan dibawa keatas dan akan ditumbuhkan di ruang penumbuhan dan juga ditumbuhkan di sekeliling lantai. Pipa kotoran sapi yang digunakan untuk mengumpulkan kotoran yang sudah tercampur oleh sekam gandum dan dibawa ke area pengeringan. Dan yang terakhir, plafon dirancang berbentuk segitiga untuk dapat menangkap gas metana yang dihasilkan sapi. karna sifat dasar metana yang lebih ringan dibandingkan oksigen, maka metana akan secara natural naik, tertangkap dan dialirkan ke tabung metana yang berada di rooftop.

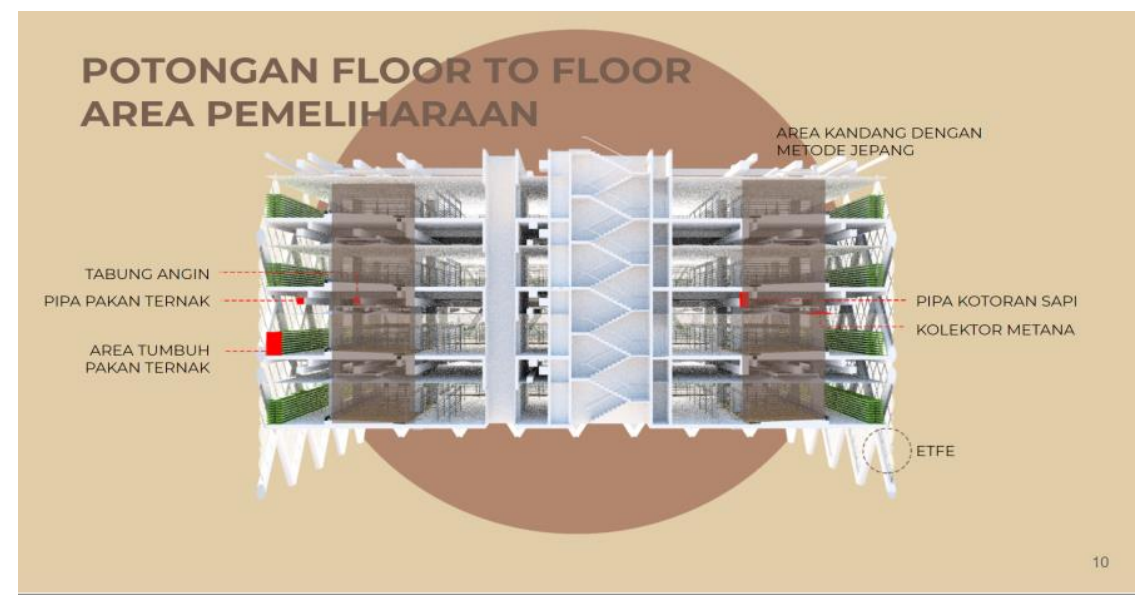

Gambar 4. Potongan dari Lantai ke Lantai

Sumber: Penulis, 2021

Terdapat beberapa sistem utama yang beerada pada program produksi yaitu sistem pengumpulan metana dihasilkan oleh gas tubuh sapi. Dikarenakan gas metana dikeluarkan oleh tubuh sapi dan kotoran sapi, maka pada area pemeliharaan dibuat sistem penangkapan metana. Area ternak dibuat indoor dengan sirkulasi angin buatan. Plafon dirancang berbentuk limas segi empat dengan pipa penyedot diatasnya. Menurut sifat metana, jika pada suhu ruangan, gas metana secara beban akan lebih ringan dibandingkan dengan udara, sehingga secara natura akan naik ke atas dan tersedot.

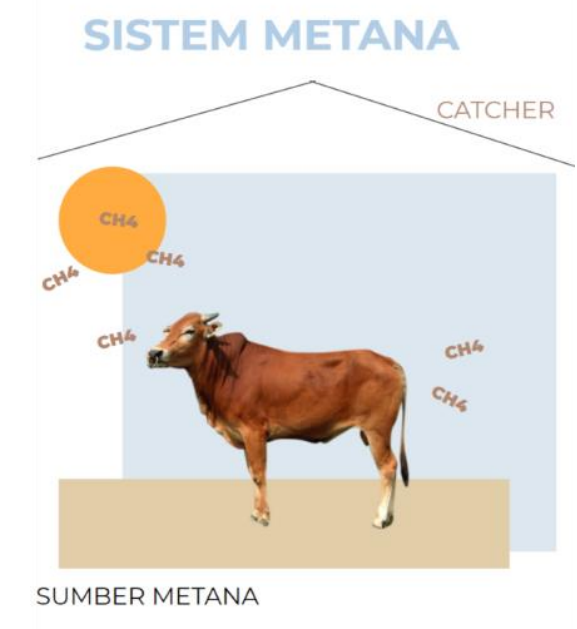

Gambar 5. Sistem Penangkapan Metana Sumber: Penulis, 2021 
Setelah tersedot, maka gas metana akan dialirkan keatas melalui pipa penyedot dan akan dinaikkan ke tabung penampungan sementara dan dinaikkan tekanannya sehingga dapat di alirkan kembali ke tabung penampungan gas metana utama pada lantai 1 dengan menggunakan pompa gas.

Sumber penghasil gas metana juga berasal dari kotoran sapi yang telah dikumpulkan. Kotoran sapi kemudian akan di panaskan dengan suhu 40 derajat selama 12 jam hingga benar benar kering. Selama pemanaaan tersebut, kotoran sapi menghasilkan gas metana secara aktif yang kemudian di kumpulkan juga dan digabungkan dengan gas metana yang berasal dari area pemeliharaan.

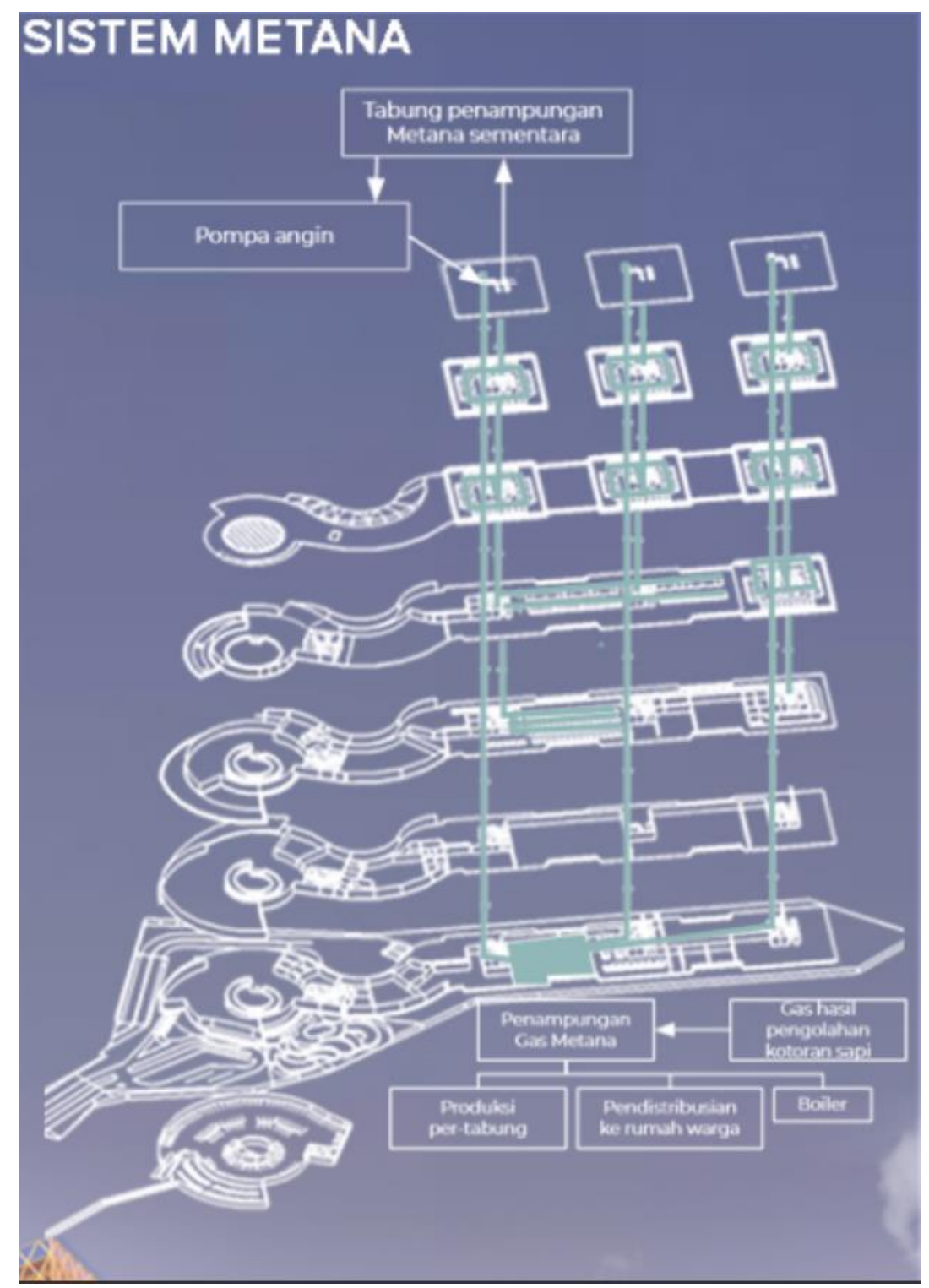

Gambar 6. Skema Metana

Sumber: Penulis, 2021

Gas yang di kumpulkan kemudian diubah kedalam bentuk cair dan disalurkan ke rumah warga yang berada di sekitar tapak dan sisanya akan dimasukkan kedalam tabung dan kemudian dijual. 


\section{KESIMPULAN DAN SARAN}

\section{Kesimpulan}

Peternakan sapi vertikal berkelanjutan ini dirancang khusus menggunakan metode eksperimen dengan memperhatikan isu efisiensi protein. Dengan mengintegrasikan perangkat pengelolaan ternak secara vertikal yang bertujuan meingkatkan efiseinsi serta menampung semua metana yang dihasilkan oleh hewan ternak dengan teknologi terbaru yang berkesinambungan serta menghasilkan produk yang sekiranya bermanfaat bagi masyarakat yang kemudian perlu didukung dengan rancangan arsitektural dengan pengelompokkan produksi dan dukungan elemen arsitektur seperti facade

\section{Saran}

Proyek ini dapat diterapkan di seluruh dunia untuk menggantikkan peternakan tradisional yang ada sehingga permasalahan efisiensi protein dapat di selesaikan.

\section{REFERENSI}

Agus, A. and Widi, T.S.M. (2018). Asian-Australasian Journal of Animal Science 31:1-8

IPCC, 2007. Climate Change 2007: Syntesis Report. A report of the intergovernmental panel IPCC, 2014. Climate Change 2014: Synthesis Report. Contribution of Working Groups I, II and III to the Fifth Assessment Report of the Intergovernmental Panel on Climate Change [Core Writing Team, R.K. Pachauri and L.A. Meyer (eds.)]. IPCC, Geneva, Switzerland, 151 pp.

Hozairi, Bakir, B. (2012). Pemanfataan Kotoran Hewan menjadi Energi Biogas untuk Mendukung Pertumbuhan UMKM di Kabupaten Pamekasan. Universitas Islam Madura. Madura.

Jelantik, I. G. N., M. L. Nulik and R. R. Copland (2009). Cara Praktis Menurunkan Angka Kematian dan Meningkatkan Pertumbuhan Pedet Sapi Bali Melalui Pemberian Pakan Suplemen. Undana Press.

Kementerian Pertanian Badan Penyuluhan dan Pengembangan SDM Pertanian Balai Besar Pelatihan Peternakan Kupang-NTT (2019). Rancang Bangun Kandang Ternak Sapi Potong

Odum, EP. (1983). Basic Ecology. Saunders, Philadelphia

Poore, J., \& Nemecek, T. (2018). Reducing food's environmental impacts through producers and consumers. Science, 360(6392), 987-992.

Rasyid, A., Hartati. 2007. Perkandangan Sapi Potong. Loka Penelitian sapi Potong Grati. Pusat Penelitian dan Pengembangan Peternakan, Deptan.

Siregar, S. B., (1996). Penggemukan Sapi. Penebar Swadaya, Jakarta.

Zoer'aini D.I. (2003). Prinsip-prinsip Ekologi dan Organisasi. PT Bumi Aksara, Jakarta 